\title{
"Democracy and National Unity Day" in Turkey: the invention of a new national holiday
}

\author{
Nadav Solomonovich
}

\begin{abstract}
On the night of July 15, 2016, the Republic of Turkey experienced yet another military coup attempt. However, this attempt failed, mainly due to civilian protest and casualties. Their sacrifice, according to the Turkish state, led to the creation of a new national celebration in Turkey, the "Democracy and National Unity Day." Following the growing interest of historians in the field of national celebrations, this paper examines the creation of this holiday. It argues that the AKP government used this new holiday to shape the Turkish collective national memory and to introduce a national celebration that does not revolve around the founder of the Turkish Republic, Mustafa Kemal Atatürk, who symbolizes the secular camp in Turkey, but rather around the Justice and Development Party government and its more traditional and religious ideology, in the guise of celebrating Turkish democracy.
\end{abstract}

Keywords: National Holidays in Turkey; 15 July Failed Coup; Commemoration; Democracy and National Unity Day; Justice and Development Party

On the night of July 15, 2016, at about $10 \mathrm{pm}$, Turkey experienced one of the most memorable events in its recent history. The entire country held its breath while watching, on television and on social media, an attempted military coup from start to finish. Tanks rolled down city streets, fighter jets bombed the parliamentary building, the president addressed his supporters via Facetime on live TV and called on all citizens to take to the streets, followed by resisting civilians being gunned down by soldiers on the Bosphorus Bridge. By the end

Nadav Solomonovich, Department of Middle Eastern and Islamic Studies, University of Haifa, 199 Aba Khoushy Ave. Haifa, 3498838, Israel; nadav.solomonovic@mail.huji.ac.il

Author's Note: The author would like to thank Eyal Ginio, Umut Uzer, and Ali Sonay for their helpful comments and remarks at the various stages of this article, as well as to the anonymous reviewers for their helpful comments and suggestions.

New Perspectives on Turkey, no. 64 (2021): 55-80 C The Author(s), 2021. Published by Cambridge University Press. This is an Open Access article, distributed under the terms of the Creative Commons Attribution licence (http://creativecommons.org/licenses/ by/4.o/), which permits unrestricted re-use, distribution, and reproduction in any medium, provided the original work is properly cited. $10.1017 /$ npt.2020.33 
of the night more than 200 of these anti-coup demonstrators would be killed and 2,193 injured. $^{1}$

After the failure of the coup attempt, purportedly planned and executed by the Gülen movement that had been engaged in a struggle with the government since 2013, the Turkish government declared a state of emergency on July 20, 2016, and used its expanded authority to pursue any alleged supporter of Gülen and his movement, conducting a massive purge of those it accused of being connected to the events, arresting and firing hundreds of thousands of people including judges, academics, journalists, civil servants and Kurdish officials. According to the website turkeypurge.com, which follows the personal stories of those dismissed or arrested, slightly fewer than a hundred thousand were arrested and more than 150,000 people were dismissed. ${ }^{2}$ But these were not the only results of the coup. One of the first steps taken by the Justice and Development Party (Adalet ve Kalkınma Partisi, AKP) government was to use the coup attempt to justify a set of political, legal, and economic changes that consolidated power in the presidency. At the same time, the party also introduced a new national holiday to celebrate Turkish democracy and commemorate those killed while attempting to protect it, "Democracy and National Unity Day" (Demokrasi ve Milli Birlik Günü), celebrated on 15 July, the anniversary of the coup.

This paper draws upon recent arguments about national holidays and the politics of memory to show how the AKP government uses this day to shape the Turkish collective national memory and to introduce a national celebration that does not revolve around the founder of the Turkish Republic, Mustafa Kemal Atatürk, who symbolizes the secular camp in Turkey, but around the populist AKP government and its more conservative and religious ideology, in the guise of celebrating Turkish democracy. In order to demonstrate how the commemoration of this holiday in the public sphere reflects the agenda of the party, this article analyses a large array of mostly new textual and visual

1 On the events of the failed coup and their various interpretations see Hakan Yavuz and Rasim Koç, "The Turkish Coup Attempt: The Gülen Movement vs. the State," Middle East Policy, 23.4 (Winter 2016), 136-48; Ateş Ali Altınordu, "A Midsummer Night's Coup: Performance and Power in Turkey's July 15 Coup Attempt," Qualitative Sociology, 40.2 (2017), 139-64; Hakkı Taş, "The 15 July Abortive Coup and Post-truth Politics in Turkey," Southeast European and Black Sea Studies, 18:1 (2018), 1-19; Feride Çiçekoğlu and Ömer Turan (eds.), The Dubious Case of a Failed Coup: Militarism, Masculinities, and 15 July in Turkey (Singapore: Palgrave Macmillan, 2019); Hakan M. Yavuz, "A Framework for Understanding the Intra-Islamist Conflict between the AK Party and the Gülen Movement," Politics, Religion \& Ideology 19.1 (2018), 11-32; Bülent Küçük and Buket Türkmen, "Remaking the Public through the Square: Invention of the New National Cosmology in Turkey," British Journal of Middle Eastern Studies, https://doi.org/10.1080/13530194.2018.1491295.

2 https://turkeypurge.com/home-page, accessed September 12, 2019. 
sources, including the activities of the Presidency of Religious Affairs (Diyanet İşleri Başkanliğı), commemorations at schools, public ceremonies, naming of public locations, building monuments, and so on. These sources suggest that the commemorations are not simply about temporal markers but also involve the transformation of spatial relationships.

The study of state nationalism as reflected in national celebrations and holidays is a growing subfield of commemoration studies. According to Elie Podeh, history has shown, particularly since the French Revolution, that new regimes may invent a calendar of celebrations while erasing or significantly changing the previous one. Alternatively, a new regime may maintain the old calendar and add new holidays to it. In such cases the calendar reflects the state's evolving national narrative. Similarly to other invented traditions and symbols used for nation building, the aim of state celebrations is to tie the individual more firmly to his or her territory ("homeland"), political community ("nation"), and the incumbent regime, through the creation of a shared historical past, memory, and values. "The national calendar, in a nutshell, tells the story of the nation, passed on from one generation to the next through holidays. In many ways, the calendar provides a reliable mirror of the core belief system of the nation. Its analysis, therefore, takes us into the very inner mechanics of nation building and state formation." ${ }^{3}$ Similarly, in her study of nationalist reforms in the early Turkish republic, Hale Yilmaz argues that national celebrations "have been important instruments of political socialization, legitimacy and mobilization in Turkey," and suggests studying them as "invented traditions" aimed at promoting the formation of Turkish national identity. ${ }^{4}$ Raja M. Ali Saleem has defined national holidays as "temporal

3 Elie Podeh, The Politics of National Celebrations in the Arab Middle East (Cambridge and New York: Cambridge University Press, 2011), 2-3. On the invention of traditions, see Eric J. Hobsbawm and Terence Ranger (eds.), The Invention of Tradition (Cambridge: Cambridge University Press, 1983). On the invention of new national holidays, see also Malte Rolf, Soviet Mass Festivals, 1917-1991 (Pittsburgh, PA: University of Pittsburgh Press, 2013); Karen Petrone, Life Has Become More Joyous, Comrades: Celebrations in the Time of Stalin (Bloomington: Indiana University Press, 2000); Gabriella Elgenius, Symbols of Nations and Nationalism: Celebrating Nationhood (Houndmills: Palgrave Macmillan, 2011).

4 Hale Yilmaz, Becoming Turkish: Nationalist Reforms and Cultural Negotiations in Early Republican Turkey, 1923-1945 (Syracuse, NY: Syracuse University Press, 2013), 179. One should note that imperial celebrations were used already during the Ottoman Empire to strengthen the legitimacy of the regime and to convey various messages to the people. On that see Hakan T. Karateke, Padişahım Çok Yaşa! Osmanlı Devletinin son yüz yılında Merasimler (Istanbul: Kitap Yayınevi, 2004); Derin Terzioğlu, "The Imperial Circumcision Festival of 1582: An Interpretation," Muqarnas 12 (1995), 84-100; Özgen Felek and Sinem Erdoğan İşkorkutan (eds.), Journal of the Ottoman and Turkish Studies Association, a special issue on "Ceremonies, Festivals, and Rituals in the Ottoman World," 6.1 (2019), 9-170. 
symbols of state nationalism," and argues that the selection of these holidays, particularly new holidays, informs how a state wishes to be seen. ${ }^{5}$

New holidays are not the only way to reflect the state's agenda; spatial markers may also serve the same purpose. And indeed, an Islamization of Turkish public space has been underway since the 1990s. Street names and city emblems have been changed to reflect the ruling parties' more religious and conservative agenda (first, the Welfare Party, and later the AKP) and large mosques were built by the state in central locations. ${ }^{6}$ According to Bülent Batuman, the AKP used the building of mosques as a "representational tool" to claim legitimacy as the true representative of the millet (nation).?

As rightly pointed out by Esra Özyürek, for many years now the AKP government has been searching for new commemorations to mark their almost two decades of rule. While they had a name for the era, "New Turkey," they did not have a holiday to mark it with. President Erdoğan repeatedly expressed how he did not think that national celebrations in the Turkish Republic reflected the entirety of Turkish, Ottoman, and Muslim history that he saw the New Turkey building upon. ${ }^{8}$

Erdoğan was right to feel this way since, according to Arzu Öztürkmen, after the Welfare Party's rise to power in the 1990s, "the celebration of national holidays symbolized support for the Republic's reforms and secularism, in opposition to rising Islamic fundamentalism." ${ }^{\text {" }}$ ztürkmen argues that other than religious holidays, in Turkey there is a long list of "important days" that can be classified into four categories. The first and most important category is that of national holidays: the opening of the Grand National Assembly by Atatürk on April 23, 1920 is celebrated as "National Sovereignty and Children's Day" (Ulusal Egemenlik ve Çocuk Bayrami) on April 23, which also emphasizes the importance of children for the country's future (a point frequently stressed by Atatürk); Atatürk's landing in Samsun on May 19, 1919 is celebrated as “Atatürk's Commemoration and Youth and Sports Day" (Atatürk'ü Anma, Gençlik ve Spor Bayrami); the ending of the War of Independence on August 30, 1923 is celebrated as "Victory Day" (Zafer Bayrami); and on October 29, 1923, the declaration of the Republic's independence is celebrated as

5 Raja M. Ali Saleem, State, Nationalism, and Islamization: Historical Analysis of Turkey and Pakistan (Cham: Palgrave Macmillan, 2017), 71-2.

6 Ibid., 73-94; Husik Ghulyan, "The Spatialization of Islamist, Populist, and Neo-Ottoman Discourses in the Turkish Capital under AKP Rule," New Perspectives on Turkey 61 (2019), 125-53.

7 Bülent Batuman, New Islamist Architecture and Urbanism: Negotiating Nation and Islam through Built Environment in Turkey (Abingdon and New York: Routledge, 2018), 31.

8 Esra Özyürek, "Commemorating the Failed Coup in Turkey," August 18, 2016, https://www.jadaliyya. com/Details/33489, accessed December 2, 2020.

9 Arzu Öztürkmen, "Celebrating National Holidays in Turkey: History and Memory," New Perspectives on Turkey 25 (2001), 47. 
"Republic Day" (Cumburiyet Bayrami). In addition, one must not forget Atatürk's Memorial Day, commemorated on November 10 (10 Kasim Atatürk'ü Anma Günü). The second category comprises other important holidays related to the Republic's reforms such as Red Crescent Week (Kizilay Haftasi) and Language Day (Dil Bayrami). The third category includes local holidays with " national significance," such as the independence day of a certain locality or a day when Atatürk paid a special visit to a particular town, for example, "the Liberation of Izmir" and "Atatürk's First Visit to Ankara". The fourth category is traditionally celebrated local festivals. ${ }^{10}$ As shown above, the vast majority of national holidays in Turkey were established by Atatürk's single-party regime, and most of them revolved around his character or his secular and western reforms or, in the words of Gizem Zencirci, "these national holidays were public displays of the new Turkish nation as cleansed from religious symbols and rituals." 11

According to Umut Uzer, prior to the 2016 coup attempt, just as Kemalist Turkey sidestepped the immediate past and preferred earlier Turkish history, the AKP government de-emphasized the republican period and focused on the Ottoman state and earlier Turkish history. National holidays that relate to the Republic were devalued or outright cancelled on the pretext of security measures. The AKP leadership instead emphasizes events from Turkish and Ottoman history such as the conquest of Istanbul and the battle of Manzikert. ${ }^{12}$

While Özyürek shares the same notion, she stresses that the AKP attempted to carve a place in the national collective memory for the more traditional population by promoting a few celebrations that reflected the party's religious ideology better, including the conquest of Istanbul by the Ottomans in 1453 or the commemoration of the birth week of the Prophet Muhammad in schools throughout Turkey, not a common practice in the rest of the Islamic world. She added that while these attempts did not fail completely, they did not produce the expected result on behalf of the party. ${ }^{13}$

10 Ibid., 48-9.

11 Gizem Zencirci, "Secularism, Islam and the National Public Sphere: Politics of Commemorative Practices in Turkey," in Alev Cinar, Srirupa Roy, and Maha Yahya (eds.), Visualizing Secularism and Religion: Egypt, Lebanon, Turkey, India (Ann Arbor: University of Michigan Press, 2012), 95.

12 Umut Uzer, "Glorification of the Past as a Political Tool: Ottoman History in Contemporary Turkish Politics," The Journal of the Middle East and Africa 9.4 (2018), 354.

13 Özyürek, "Commemorating the Failed Coup in Turkey." The conquest of Istanbul was already celebrated in the late Ottoman Empire in 1914, as well as the Prophet's birthday, see Eyal Ginio, The Ottoman Culture of Defeat: The Balkan Wars and Their Aftermath (New York: Oxford University Press, 2016), 235-6. It reappeared in Turkey during the 1950s; see Gavin D. Brockett, "When Ottomans Become Turks: Commemorating the Conquest of Constantinople and Its Contribution to World History," The American Historical Review 11.2 (2014), 399-433; Nicholas Danforth, "Multipurpose Empire: Ottoman History in Republican Turkey," Middle Eastern Studies 50.4 (2014), 655-78. The celebrations received more coverage under the Welfare Party (Refah Partisi) in the 1990s; see Alev Çınar, "National History as a Contested Site: The Conquest of Istanbul and Islamist Negotiations of the Nation," Comparative Studies in Society and History 43.2 (2001), 364-91. 
But how did the events of the failed coup transform into a new invented tradition in the form of a national celebration, and how did these celebrations reflect the AKP's agenda? According to Yael Zerubavel, national myths preach and promote the notion of self-sacrifice for the greater good of the state. In return, the state assures the remembrance of personal sacrifice by public commemorations such as rites (national ceremonies and military funerals), fixed days (memorials), material objects (monuments), and assigned spaces (military cemeteries) that transform the private person to a national symbol. ${ }^{14}$ As I will demonstrate below, the new "Democracy and National Unity Day" includes many of these forms of commemoration, but many of them also include Islamic and even Ottoman past traditions and practices.

Referring to monuments, Maoz Azaryahu, who worked on commemoration in Israel, argued that they reflect the power relations that prevailed at the time of their construction. ${ }^{15}$ This is of course true, but in no way limited only to the construction of monuments. All commemorative practices at any given time reflect the contemporary hegemonic narrative as much as they do the war or events they are supposed to commemorate. In other words, examination of the commemoration practices of the failed coup attempt may suggest that there is much more to the "Democracy and National Unity Day" than commemorating the civilians who sacrificed their lives on July 15, 2016.

\section{Rites and celebrations}

While Islam was always unofficially a part of many commemorative projects, the observance of July 15 marks the first time that a national holiday has been explicitly and deliberately "Islamized" by the state. In 2017, July 15 was declared an official holiday in Turkey. The first anniversary of July 15 included many commemorative events. While the commemorations also included Ottoman and modern commemorative elements, the dominant vocabulary was that of Islam. For example, the events under the auspices of the presidency focused on the martyrs (şehit) and their families, such as visiting martyrs' graves, commemoration events with the participation of families of martyrs and warriors for Islam (gazi - in modern Turkish also signifying "veteran"),

14 Yael Zerubavel, "Battle, Sacrifice, and Martyrdom: Continuity and Change in the Conception of Patriotic Sacrifice in Israeli Culture," in Avner Ben-Amos and Daniel Bar-Tal (eds.), Patriotism (Tel Aviv: Hakibbutz Hameuchad \& Dyonon, 2004), 61-99 (in Hebrew); Barry Schwartz suggests a slightly different division, see Barry Schwartz, "Commemorative Objects," in Neil J. Smelser and Paul B. Baltes (eds.), International Encyclopedia of the Social and Behavioral Sciences (Amsterdam: Elsevier, 2001), 2268.

15 Maoz Azaryahu, "From Remains to Relics: Authentic Monuments in the Israeli Landscape," History and Memory 5.2 (1993), 84. 
and so on. Some of these events took place at the AKP headquarters, which only ties the national holiday more closely to the party. In his address to family members of the civilians killed or injured in the Beştepe People's Congress and Culture Center in Ankara, two weeks after the failed coup attempt, President Erdoğan used many religious motifs, mentioning that those who participated in the coup were infidels (kafir), and that those who died trying to prevent it were martyrs and would be embraced by Allah and the Prophet. ${ }^{16}$ That was not the only instance in which Erdoğan used such terms. In a speech to inaugurate the monument built in Istanbul on July 15, 2017, Erdoğan used religious terms, tying Turkish nationalism to Islam:

What did our people who stood against them have? Did our citizens have weapons in their hands? Like today, they held in their hand only flags, but they had a much more powerful weapon, and that weapon was faith. [...] Do you know what God has promised the martyrs? For those who fight in the way of God, or in the way of their country and nation? He has promised them paradise. ${ }^{17}$

The terms şehit and gazi used by Erdoğan and the state to describe the casualties and "veterans" of the coup also require our attention. These terms, used in Turkey to describe fallen soldiers or those who died in the name of the national cause or war veterans, also have religious connotations since they appear in the Quran. As pointed out by Timur Hammond, "Naming those who died during the fighting as 'martyrs' - and not simply 'casualties' or 'victims'-elevates the role of the protestors to a sacred act." ${ }^{18}$ According to Nurseli Yeşim Şünbüloğlu, the state's use of these terms to describe civilians was criticized by military veterans. ${ }^{19}$

16 President Erdoğan in the Beştepe People's Congress and Culture Center in Ankara, July 29, 2016. Available on the official website of the Turkish Presidency, https:/www.tccb.gov.tr/MainPages/ PlayVideo?GalleryltemID=62516, accessed September 25, 2019.

17 President Erdoğan's speech in Istanbul on 15 July 2017, https://www.youtube.com/watch?v= fxxiPvVP56o, accessed October 12, 2019.

18 Timur Hammond, "Making Memorial Publics: Media, Monuments, and the Politics of Commemoration following Turkey's July 2016 Coup Attempt," Geographical Review (2020), 8, https://www.tandfonline.com/action/showCitFormats?doi=10.1080/00167428.2019.1702429. On civil Martyrdom in Turkey see Pınar Melis Yelsalı Parmaksız, "The Transformation of Citizenship before and after the 15 July Coup Attempt: The Case of Civil Martyrdom," in Nikos Christofis (ed.), Erdoğan's "New" Turkey: Attempted Coup d'état and the Acceleration of Political Crisis (London: Routledge, 2019), 113-24. The terms şehit and gazi were already used in a religious context in the 1950s as part of Turkey's participation in the Korean War. On that, see Nadav Solomonovich, "The Turkish Republic's Jihad? Religious Symbols, Terminology and Ceremonies in Turkey during the Korean War 1950-1953," Middle Eastern Studies 54.4 (2018), 592-610.

19 Nurseli Yeşim Şünbüloğlu, "Contending Sacrifices: Discontent of Military Veterans of the Kurdish Conflict for Civilian Veterans of 15 July," in Çiçekoğlu and Turan, The Dubious Case of a Failed Coup, 41-70. 
Furthermore, the notion of being oppressed is crucial to the AKP's populism. According to Özpek and Yaşar, populism refers to "the people" for legitimacy, it is rooted in anti-elite feelings, it constructs an "us vs. them" dichotomy with an exclusion strategy, and it forges mass mobilization. They also argue that Islamism can be combined with populism. ${ }^{20}$ If in the past the AKP depicted the Kemalists as the oppressors, the failed coup had given them a new enemy to rally against. ${ }^{21}$ Thus, the invention of the holiday and its commemorations are part of a co-optation strategy that consolidates a part of society around the party-state and its leader Erdogan.

The anniversary is also present in the public sphere: many posters were hung in central locations (sometimes at the initiative of the municipality); in July 2018 a temporary complex, including various commemorative elements, was constructed by the Beyoğlu Municipality in Taksim Square in Istanbul; ${ }^{22}$ photo exhibitions on July 15 were held in various public places (for example, in Beyazıt State Library in Istanbul); ${ }^{23}$ and the national TV network, TRT (Turkish Radio and Television Corporation), produced documentaries on the martyrs, interviewing their family members and telling their stories. ${ }^{24}$ Internet websites were also used by the Office of the Presidency and by the government-leaning newspaper Yeni Safak to commemorate the martyrs. ${ }^{25}$ According to Donald M. Reid, stamps are excellent primary sources for the symbolic messages which governments seek to convey to their citizens and to the world. "Stamps resemble government buildings, monuments, coins, paper money, flags, national anthems, nationalized newspapers, and ambassadors as conveyors of official viewpoints." ${ }^{26}$ The state organized a nationwide competition to design a commemorative stamp via the Turkish post (Posta Telgraf Telefon, PTT). The two winning stamps, in which the public is shown preventing tanks from advancing, were indeed revealed and published before the first anniversary in $2017 .{ }^{27}$

20 Burak Bilgehan Özpek and Nebahat Tanriverdi Yaşar, "Populism and Foreign Policy in Turkey under the AKP Rule," Turkish Studies 19.2 (2018), 202-3.

21 On the perceived victimhood of the AKP, see Zafer Yilmaz, "The AKP and the Spirit of the 'New' Turkey: Imagined Victim, Reactionary Mood, and Resentful Sovereign," Turkish Studies 18:3 (2017), 482-513.

22 Timur Hammond, "The Politics of Perspective: Subjects, Exhibits, and Spectacle in Taksim Square, Istanbul," Urban Geography 40.7 (2019), 1039-54.

23 Samet Doğan, "Beyazıt Kütüphanesi'nde AA'nın 15 Temmuz sergisi ilgi görüyor," Anadolu Ajansı, October 14, 2016, https://www.aa.com.tr/tr/kurumsal-haberler/beyazit-kutuphanesinde-aanin-15temmuz-sergisi-ilgi-goruyor/664956, accessed December 2, 2020.

24 TRT, "15 Temmuz Kahramanları," http://www.trt.net.tr/15temmuzkahramanlari/, accessed October 5, 2019.

25 On that topic, see Hammond, "Making Memorial Publics," 6-10.

26 Donald M. Reid, "The Symbolism of Postage Stamps: A Source for the Historian," Journal of Contemporary History 19.2 (1984), 223-34.

27 Haberler.com, "PTT A.Ş.'den 15 Temmuz Şehitlerimiz Anısına Pul Tasarım Yarışması," February 15, 2017, accessed December 2, 2020. 
Ottoman traditions were also present in the celebrations although not to same extent as the Islamic ones. One such example was the performance of the Mebteran, the Ottoman military band, which participated in the main event of July 15, 2017 in Istanbul, right before Erdoğan's speech. ${ }^{28}$

While there is no official moment of silence to commemorate the martyrs (as in the commemoration of Mustafa Kemal Atatürk), ${ }^{29}$ there are many occasions of recitation of prayers in their honor. For example, in 2017 Erdoğan participated in four different events in which Quran verses were recited within the space of six hours. The importance of this tradition is also demonstrated by a circular sent by the Diyanet to the Provincial and District Mufti Offices on July 5 , 2018 in preparation for the second anniversary of July 15. It highlighted the importance of transforming the "July 15 spirit" into a common consciousness among children and the nation and announced a campaign named: "We are reading the Quran for our martyrs." A complete recitation of the Quran was to be undertaken at least once in every mosque. According to the circular, at the time at which the coup attempt was carried out, at 00.13 at night, 90,000 mosques across Turkey were to recite a prayer once. The mosques were also to remain open until the morning prayer, and their minarets illuminated. ${ }^{30}$

But rites were not the only way to include religious elements in the commemoration of July 15. Since many Islamic messages and practices are embedded in July 15, the Presidency of Religious Affairs, the highest religious authority in Turkey, also plays an important part in the religiosity of this memorial.

\section{The Diyanet and the holiday's commemoration}

And as a nation [millet], we witnessed a year ago on July 15 that Allah's assurance was realized. That night, we faced a big attempt of [sic] treason

28 According to Kuçük and Türkmen, Mehter music was also played in the "democracy watches" after the coup. Küçük and Türkmen, "Remaking the Public through the Square," 14. On the historic role of the Mehter, see Wendy M.K. Shaw, Possessors and Possessed: Museums, Archaeology, and the Visualization of History in the Late Ottoman Empire (Berkeley: University of California Press, 2003), 196-8.

29 On the commemoration of Atatürk, see Christopher S. Wilson, Beyond Anitkabir: The Funerary Architecture of Atatürk-The Construction and Maintenance of National Memory (Farnham: Ashgate, 2013). On Moments of Silence see Vered Vinitzky-Seroussi and Chana Teeger, "Unpacking the Unspoken: Silence in Collective Memory and Forgetting," Social Forces 88.3 (March 2010), 1103-22.

30 Diyanet, "Diyanet'ten 15 Temmuz'a özel hazırlık," July 5, 2018 https://www.diyanet.gov.tr/tr-tr/ Kurumsal/Detay/11737/diyanetten-15-temmuza-ozel-hazirlik, accessed 28 September 2019. On Diyanet see Ahmet Hadi Adanali, "The Presidency of Religious Affairs and the Principle of Secularism in Turkey," The Muslim World, 98 (April/July 2008), 228-41; Amit Bein, Ottoman Ulema, Turkish Republic: Agents of Change and Guardians of Tradition (Stanford, CA: Stanford University Press, 2011), 136-53. 
and invasion as a country and nation. On that dark night, we witnessed once again that Allah did not spare His favor, grace, assistance, and blessing from us. For that reason, our most important duty on the anniversary of July 15 is to never forget Allah's favor and grace, His mercy and assistance. As believers who overcame this great calamity shoulder to shoulder, we must always thank Allah, show gratitude to Him, and prostrate ourselves before Him.

Diyanet sermon in commemoration of July $15,2017 .^{31}$

One of the Diyanet's main activities regarding July 15 is its annual sermon, addressing the public across the nation. As seen from the excerpt above, these sermons explain the failure of the coup and the survival of Turkish democracy as a result of no less than a divine intervention. The sermon, which includes Quranic verses, also compares July 15 to other historical battles in which Allah aided his Turkish believers such as at Manzikert (Malazgirt, 1071), Çanakkale (Gallipoli, 1915), Sakarya and Dumlupinar (both in the Turkish War of Independence, 1919-22). The sermon also praised the unity shown by the Turkish nation in its attempt to stop the coup while using religious language and referring to the importance of Islam in preventing the coup, thus strengthening the religious importance of commemorating the event:

We all witnessed on July 15 that our glorious nation [millet] took to the streets upon the call of our statesmen to defend their own homeland, rights, law, free will, independence, and freedom with takbir on their lips, sala [prayer] in their ears, and the desire for martyrdom in their hearts. [... ] Particularly the fact that our youth performed ablution saying "bismillah", left home reciting the Kalima Shahadat, and took to the streets with "Allahu Akbar" chants was the biggest hope for the future of our nation. ${ }^{32}$

Interestingly, while the government or the president are not explicitly mentioned in the sermon, it is completely clear that the "statesmen" who called the public to take the streets are President Erdoğan and the members of the AKP, which also strengthens the ties between the July 15 celebrations and the government.

One of the methods the Diyanet adopted to shape the public discourse relating to the failed coup was to include articles on the topic in its official journal, Diyanet. The articles published in Diyanet addressed their readers by offering a clear dichotomy between the general public, loyal to Turkish democracy, and

31 The Presidency of Religious Affairs, "The Glorious Resistance that Salas [Prayers] Bore Witness: 15 Temmuz," July 14, 2017, http://www2.diyanet.gov.tr/DinHizmetleriGenelMudurlugu/HutbelerListesilngilizce/ The\%20Glorious\%20Resistance\%20That\%20Salas\%20Bore\%20Witness;\%2015\%20Temmuz.pdf, accessed 28 September 2019.

32 Ibid. 
the Fethullah Gülen Terrorist Organization. The Diyanet also used its children's journal to introduce the new generation to the "Democracy and National Unity Day." Since it was aimed at children, the journal presented the holiday and events in a seemingly innocent way that included religious symbols and language and encouraged self-sacrifice for the Turkish homeland, by means of short stories, poems, comics, games, and questionnaires. ${ }^{33}$ One such questionnaire, titled "Hero test" (Kahraman Test), asked questions about the "proper" way a hero should act. This test included questions such as "What is someone who sacrifices his life in the path of Allah called?" or "Who is the most unforgettable name among the July 15 martyrs [şehitler] listed below?"34 Another way of introducing the holiday was using games; for example, by finding differences between two pictures of the July 15 Martyrs monument in Istanbul. This game not only introduced the monument to children, but by mentioning that their friends go there puts pressure on them to visit the place as well..$^{35}$ Another Diyanet publication for children, a book titled My Homeland Is Everything (Vatanim Her Şeyim), also used the same means, including new stories and poems, testimonies of warriors for Islam (gazi), and republished sections of the abovementioned children's journal. ${ }^{36}$

The Diyanet, as well as other official institutions, does not limit itself to traditional ways of shaping the public discourse. More modern means such as the internet and social media are also being used for the same purpose: short video clips, posters, photos, booklets, speeches, and even prayers are available on the official websites of the Diyanet ${ }^{37}$ and the Presidency of the Republic of Turkey. ${ }^{38}$ Commemoration is not limited to locations and public ceremonies. Education is one of the most crucial components for creating or promoting collective memory by celebrating or commemorating state holidays, myths, traditions, or memorials.

\section{Commemorating the holiday in school}

Most scholars tend to agree on the importance of the education system and school textbooks for inculcating the youth with a shared collective identity, although their impact is diminishing with the growing exposure of young

33 Diyanet Çocuk Dergisi, 444 (Temmuz, 2017), 12-13, 17, 39; Diyanet Çocuk Dergisi, 456 (Temmuz 2018), 13, 27, 45, 48; Diyanet Çocuk Dergisi, 468 (Temmuz 2019), 18-19, 25, 34-5, 42-3.

34 Diyanet Çocuk Dergisi, 444 (Temmuz 2017), 12-13.

35 Diyanet Çocuk Dergisi, 468 (Temmuz 2019), 25.

36 https://webdosyasp.diyanet.gov.tr/egitimmerkezi/UserFiles/15temmuz/Files/Kitaplar/Vatanim\% 20Her\%20\%C5\%9Eeyim.pdf, accessed December 2, 2020.

37 The Presidency of Religious Affairs website, https://15temmuz.diyanet.gov.tr/, accessed October 1, 2019.

38 The Presidency of the Republic of Turkey website, https://www.tccb.gov.tr/faaliyetler/15temmuz/, accessed October 1, 2019. 
people to social media. ${ }^{39}$ According to Arzu Öztürkmen, the main reasons that "Victory Day" never attained the importance of the other national holidays were that it did not fall within the school year and the fact that it had more of a military character than a civilian one. ${ }^{40}$ Since publishing a new textbook takes time, and since July 15 also falls outside the school year and may have faced the same problem as "Victory Day," the current government announced, via a circular published by the Ministry of National Education in preparation for the academic year of 2016-17, that schools should dedicate the first week of the school year to commemorating the martyrs of July 15 . The circular also contained very detailed information on the necessary activities to be undertaken by the schools, including the type of activities, the specific dates on which they should be held, and the person or institute responsible for the planning and execution of these events. For example, every class was required to create a panel board including pictures, news, or stories regarding July 15 within the first week of school (September 19-23, 2016), to be hung on the classroom wall and the class teacher was responsible for organizing this board with his/her students. ${ }^{41}$ In addition, each school was tasked with dedicating "memorial corners" for the "July 15 Victory of Democracy and Martyrs" at its entrances, which would include photographs, proverbs, verses of the Quran and Hadith (religious traditions) on the topic of martyrdom, and other relevant texts. ${ }^{42}$ Similarly, two short videos produced by the Ministry of Education were screened to the lower secondary and secondary school students, which included equating the civilian mobilization on July 15 to that of the Ottomans at Gallipoli and the Turks in the War of Independence. While both videos include the image of Mustafa Kemal Atatürk, they also included religious motifs and language such as photos of praying civilians and mosque minarets. They also included many references to the AKP and especially to Erdoğan, whose recordings and voice-over are included in a large part of the clips, as well as real footage from the coup attempt and national symbols, especially the Turkish flag. ${ }^{43}$

39 For a short discussion, see Samira Alayan and Elie Podeh, "Introduction: Views of Others in School Textbooks-A Theoretical Analysis," in Elie Podeh and Samira Alayan (eds.), Multiple Alterities: Views of Others in Textbooks of the Middle East (Cham: Palgrave Macmillan, 2018), 1-4. Öztürkmen, "Celebrating National Holidays in Turkey," 71-2.

41 Mehmet Acikalin and Hamide Kilic, "The Role of Turkish National Holidays in Promoting Character and Citizenship Education," Journal of Social Science Education 16.3 (2017), 78-9.

42 Milli Eğitim Bakanlığı, "15 Temmuz demokrasi zaferi ve şehitleri anma etkinlikleri programı," September 19-23, 2016, https://ogm.meb.gov.tr/meb_iys_dosyalar/2016_09/08101839_15_temmuz_ demokrasi_zaferi_ve_sehitleri_anma_etkinlikleri_programi_pdf, accessed September 26, 2019 (hereafter: Milli Eğitim Bakanlı̆ı, Circular). Memorial corners were also constructed in schools in the Ottoman Empire after its defeat in the Balkan Wars (1912-13). On that see Ginio, The Ottoman Culture of Defeat, 171.

43 These videos are available on YouTube: https://www.youtube.com/watch?v=T6GzVeLqNSE;https:// www.youtube.com/watch?v=0Unlrb-EMLO, accessed on 10 October 2019. 
The circular also affected the school's curriculum. For example, Turkish literature teachers in all classes were instructed to have their students write letters to the heroes of July 15 and express their feelings about this event. In addition, teachers of Turkish literature, social studies, history, and religious education were instructed to recite texts and poems on topics such as democracy, martyrdom, the nation's will, and the defense of the homeland in their classes during the first week of school. The circular also included other activities that should be addressed during the whole academic year such as organizing school contests in various fields such as painting, photography, poster design, video, theater, and writing on the theme of "July 15 from students' perspectives." Other activities included meeting with families of the martyrs (if there were any in the province) and field trips to locations where clashes between the coup forces and the people took place. Schools were also instructed to plant a forest in memory of the martyrs in their city within this school year. ${ }^{44}$

The Ministry of National Education issued another program for the commemoration ceremony itself. This program was very detailed and included the school headmaster's speech and all the poems and speeches to be read by selected students in each school. For example, all ceremonies should start with the singing of the national anthem followed by the recitation of Surat al-Fatiha for the souls of the martyrs. ${ }^{45}$ According to Podeh, the anthem is a formal symbol transferred by music and performance, which also conveys a message of sacredness. It helps to give form to an event by marking its opening and closing. ${ }^{46}$ Referring to the Jewish commemorative prayer, Yizkor, in memorials in Israel, Ben-Amos and Bet-El argue that the ceremonies cannot be considered completely secular affairs and "the very act of employing prayer in the ceremonies bears witness to their religious nature and links them to the historical narrative in which the Jewish people metamorphose from a religious community to a modern national one." 47 The Turkish case, I would argue, bears some resemblance to the Israeli one in the sense that although the Yizkor is strictly a commemorative prayer (unlike al-Fatiba), the latter also conveys a message of sacredness to the ceremony. On the other hand, one should remember that the recitation of al-Fatiba was always considered a traditional cultural norm in Turkey, which also helped it survive the extreme

44 Milli Eğitim Bakanlığı, Circular; Acikalin and Kilic, "The Role of Turkish National Holidays," 79.

45 Milli Eğitim Bakanlığı, "15 Temmuz demokrasi zaferi ve şehitleri anma programı," 1, September 18, 2016, http://img.eba.gov.tr/897/98a/3df/b4a/8f9/3a4/a0f/818/944/99f/1f4/615/154/a34/001/ 89798a3dfb4a8f93a4a0f81894499f1f4615154a34001.PDF (hereafter: Milli Eğitim Bakanlığı, "Commemoration Ceremony"), accessed September 24, 2019.

46 Podeh, The Politics of National Celebrations, 30.

47 Avner Ben-Amos and Ilana Bet-El, "Holocaust Day and Memorial Day in Israeli Schools: Ceremonies, Education and History," Israel Studies 4.1 (1999), 275-6. 
secularization reforms of Atatürk in the 1920s and 1930s and should therefore perhaps not be viewed as strictly religious.

The headmaster's speech is probably the most detailed and interesting text in the program. It compares the events of July 15 to those of the War of Independence, referring to local heroes that rose up to protect the Turkish homeland. The conspirators are compared to robbers who wanted to enslave "our hopes, our dreams and our freedoms" but were repelled by the children of this land who were raised on Yunus Emre, Mevlana, Hac1 Bektaş, Hac1 Bayram Veli, and other Turkish role models. At the end of speech the martyrs (şehitler) and warriors for Islam (gaziler) are lauded for showing us once more "how a land becomes a homeland, and how it remains a homeland." 48 ss in the above-mentioned sermon of the Diyanet, other texts in the program also compare July 15 to the Turkish War of Independence, and the historic battles of Gallipoli and Manzikert, but with less emphasis on Allah's role in achieving victory. Interestingly, while the poems selected for the ceremony were written by authors from very different backgrounds and beliefs, ranging from Islamists such as Mehmet Akif Ersoy (author of the Turkish National Anthem) and Necip Fazll Kısakürek, to the communist Nâzım Hikmet, they were all harnessed for the commemoration of the fallen and the promotion of Turkish patriotism. ${ }^{49}$

While the Ministry of Education allowed schools to add relevant texts to the ceremony, great similarity in the ceremonies' structure and reading selections, from the headmaster's speech to the poems read by the students, consolidates the state's narrative and promotes the students' national conscience. Interestingly, I did not find any indication that the Ministry of Education decided on a fixed time for the ceremonies to be held, which might have contributed to the promotion of nationalism among the students since, according to Ben-Amos and Bet-El, "[ $\mathrm{t}]$ he simultaneous observance of ceremonies also coincided with the modern concept of national time, based on the imaginary unity of the community synchronically commemorating the same historical event in like form." 50

According to an article published in Cumburiyet on April 5, 2018, the Ministry of National Education organized dozens of activities for school children on the July 15 coup attempt and even organized special activities for preschoolers. According to the article, the Ministry of National Education launched a project titled "July 15 in the Eyes of Children," which was aimed mainly at children aged between five and six and was tasked with "keeping the

48 Milli Eğitim Bakanlığı, "Commemoration Ceremony," 3.

49 On the "rediscovery" and commemoration of Mehmet Akif Ersoy as a national hero by the AKP, see Saleem, State, Nationalism, and Islamization, 74-8.

50 Ben-Amos and Bet-El, "Holocaust Day and Memorial Day in Israeli Schools," 275. 
spirit of national unity and solidarity" and fostering "a sense of democracy and patriotism" among the children. ${ }^{51}$ However, it was unclear how exactly these objectives were supposed to be achieved.

In July 2019 the Ministry of National Education also published a special online journal, titled: July 15 Democracy and National Unity Day. The 44-page journal included articles written by family members of the martyrs, interviews, and the seven winning essays (one from each province) from the nationwide competition "Students Write: July 15, From a Coup to Democracy." These essays were accompanied by pictures drawn by students from art schools across Turkey. In addition, the journal also published the seven winning essays of teachers in a similar contest. ${ }^{52}$ The ministry's website also announced additional competitions for short films, posters, and handcrafts. ${ }^{53}$

\section{Changing names}

As stated above, commemoration has many forms. As Maoz Azaryahu showed in several of his works, the naming of streets holds a commemorative power. According to him, the use of street names for commemoration reflects the political culture and the hegemony's attempt at creating or promoting a shared past. $^{54}$ According to Derek H. Alderman, the size and importance of the location chosen for the commemorative street are extremely important and may lead to struggles between various groups. In other words, Alderman argues that "[a] prominent, frequently travelled street would represent a larger and more significant scale of memorialization than a small side road because of

51 Ozan Çepni, "Çocuklara 15 Temmuz! Milli Eğitim Bakanlığı, 5-6 yaşındaki çocuklara darbe girişimini soracak," Cumhuriyet, April 5, 2018, online edition, -http://www.cumhuriyet.com.tr/haber/egitim/ 953813/Cocuklara_15_Temmuz_Milli_Egitim_Bakanligi_5-6_yasindaki_cocuklara_darbe_girisimini_ soracak.html, accessed December 2, 2020.

52 Milli Eğitim Bakanlığı, "15 Temmuz Demokrasi ve Milli Birlik Günü," July 15, 2019, http://www.meb.gov.tr/ 15temmuz/2019/?fbclid=IwAR0sTZNW6uvVEOEa8CTqBtsoS8BPG6VbphWZQxwCfg1XPd0hGSBw6CkJum0, accessed September 24, 2019.

53 Milli Eğitim Bakanlığı, "15 Temmuz Demokrasi Ve Millî Birlik Günü Anma Etkinlikleri," April 5, 2019, http://hbogm.meb.gov.tr/www/15-temmuz-demokrasi-ve-mill-birlik-gunu-anma-etkinlikleri/icerik/ 912, accessed October 3, 2019.

54 Maoz Azaryahu, "The Power of Commemorative Street Names," Environment and Planning D Society and Space 14.3 (1996), 311-30; Maoz Azaryahu, "Street Names and Political Identity: The Case of East Berlin," Journal of Contemporary History 21.4 (1986), 581-604. On the politics of street naming in Turkey see Aygen Erdentuĝ and Berrak Burçak, "Political Tuning in Ankara, a Capital, as Reflected in Its Urban Symbols and Images," International Journal of Urban and Regional Research, 22.4 (1998), 589-601. For a historical review on locations name change in Turkey, see Kerem Öktem, "The Nation's Imprint: Demographic Engineering and the Change of Toponymes in Republican Turkey," European Journal of Turkish Studies, 7-Demographic Engineering-Part I (2008), https://journals.openedition.org/ejts/2243. 
differences in the amount of public exposure and visibility that each road brings to a memorial cause. ${ }^{" 55}$ One should remember that changing the names of locations as a means of memorialization is also the cheapest and easiest form of commemoration - although not always the most effective, since more often than not people tend to use the old name rather than adopting the new one. In addition, once people get used to the street's name and use it as a locality it tends to lose its commemorative power. Despite its possible shortcomings, the Turkish government decided that naming locations would be one of the means used to commemorate the fallen. In the abovementioned speech given by Erdoğan in Beştepe on July 29, 2016, he stressed that the martyrs will be commemorated by the state:

each and every one of them [the martyrs] is known to the nation and they will remain known forever [...] [for that reason] we have renamed the Bosphorus Bridge the July 15 Martyrs Bridge. The intersection where the Parliament and Chief of Staff premises are located has been renamed the July 15 Martyrs Square. The Kizilay Square has been renamed the July 15 Kizilay Democracy Square. And now we will monumentalize the names of each and every one of our 237 martyrs. ${ }^{56}$

The Turkish government did not choose these locations by accident. These are not only some of the most important and central locations in Turkey's major cities, but places in which the public concentrated on July 15 attempting to prevent the coup. As such, these locations also carry a symbolic meaning, reminding the public of its own contribution in stopping the coup. In addition, the Ankara municipality, controlled at the time by the AKP, placed "15 Temmuz Destanı" installations in other important locations in Ankara, such as the Çankaya Palace, the Grand National Assembly, and the General Staff of the Republic of Turkey. ${ }^{57}$ Those locations, while being key foci wherein the coup unfolded, are also considered iconic sites in terms of reflecting early republican Turkey. By placing these installations, the AKP also attempted to reappropriate and redefine the symbolical importance of those locations. A case in point is the installation placed next to the Güven Monument at Kizılay Square, the most iconic monument of early republican Ankara, where

55 Derek H. Alderman, "Street Names and the Scaling of Memory: The Politics of Commemorating Martin Luther King, Jr. within the African American Community," Area 35.2 (2003), 165-6.

56 The number of martyrs later rose to 249. President Erdoğan's speech, July 29, 2016.

57 Star, "Devletin zirve mekanlarına '15 Temmuz Destanı' yazılıyor," July 14, 2017, https://www.star.com. tr/yerel-haberler/devletin-zirve-mekanlarina-15-temmuz-destani-yaziliyor-103517/, accessed December 2, 2020. 
tens of thousands of people pass by each day..$^{58}$ The installation, which was placed in a central and visible location, is therefore experienced more intensively than the Güven Monument and thus redefines the experience of the square. Another step planned by the municipality was to keep the bullet holes and damage caused to the Güven Monument during the coup attempt to serve as a constant reminder of its failure. ${ }^{59}$

The AKP government did not settle for the abovementioned places alone. Other public locations including hospitals, schools, mosques, train stations, bus stops, and so on were also named after July 15 or given the names of specific martyrs. But renaming locations was only one of the steps taken by the government for the spatial commemoration of the holiday.

\section{Sacred spaces? The July 15 monuments}

One of the most important means of commemoration at the state's disposal is building monuments. According to Maoz Azaryahu, monuments "embod[y] the link between history and geography, community and terrain, society and environment, culture and nature in the process of forging an identity between past and present." The size and topographical location of monuments determines the amount of public exposure they receive and the attention they attract to themselves and to the story they wish to tell. Azaryahu added that there are two main types of monuments: remote monuments which sometimes become tourist attractions, and monuments situated in city centers which are constantly encountered by passers-by. The main difference between the two is that "remote monuments may be less frequented, but the encounter with them is characterized by intense awareness of their significance. City monuments, by contrast, are woven into the urban texture so that a maximal number of random encounters is guaranteed, although each encounter carries a low charge of symbolic potential." The monument's location also affects their symbolic significance. Monuments built at the place they were designed to commemorate attain an "aura of sacredness" while monuments located in city centers "endow their location with sacredness." ${ }^{10}$ While monuments commemorating the coup

58 On the symbolic importance of Güven Monument in early Republican Turkey, see Bülent Batuman, "Identity, Monumentality, Security: Building a Monument in Early Republican Ankara," Journal of Architectural Education 59.1 (2005), 34-45.

59 "Güven Anıtı́nın '15 Temmuz' yarası unutturulmayacak", Büyükşehir Ankara 607, November 8-15, 2016, 20. A similar technique was used in the Martyrs' Square Monument in Beirut after the civil war, see Nour Dados, "Revisiting Martyrs' Square ... Again: Absence and Presence in Cultural Memory," in Ladina Bezzola Lambert and Andrea Ochsner (eds.), Moment to Monument: The Making and Unmaking of Cultural Significance (Bielefeld: Transcript, 2009), 174.

60 Azaryahu, "From Remains to Relics," 84-5. 
were established throughout the country, the main two are those built in the capital, Ankara, in front of the president's residence, and in Istanbul, near the newly renamed July 15 Martyrs Bridge. These two monuments are very different in many aspects. The Istanbul monument is located in a relatively central place where thousands pass by every day and also at the place where the events took place. However, very little sense of "sacredness" is involved since most of the encounters with it occur by car, driving on the July 15 Martyrs Bridge. The Ankara monument fits Azaryahu's description better, since it is in a somewhat remote place (although very important symbolically) near the presidential residency. It seems that the monument's location was chosen for two main reasons. First, to show the importance ascribed to the events by the current ruling party and president as well as the direct link between them. Since the presidential residency faces the monument it is impossible to separate the two. Second, to attract tourists: since the July 15 Museum is currently under construction nearby, the combination of the two may well create the "aura of sacredness" mentioned by Azaryahu and possibly gain support for the president who was targeted by the coup attempt. Another possibility is that the monument's location was also intended as a declarative measure, to say, "I am still here", in spite of the coup planners' efforts.

The monuments are also very different is shape and size. The Istanbul monument stands next to 250 cypress trees and rose bushes that represent the 250 people who lost their lives in the coup. It is designed as an open pentagonal dome, almost ten meters tall with an eleven-meter diameter. It includes five arches, two of which are used to enter or leave the monument while the other three are used as inscription niches where the names of the martyrs were inscribed. Under the dome, at the center of the monument, a muqarnas (an ornamented vaulting peculiar to Islamic architecture) was built, and above it, on the dome, is an Arabic inscription "Hüvel-Şebid" - "He is the Martyr." Another inscription includes Surat al-Baqara verse 154: "And do not say about those who are killed in the path of Allah, 'They are dead.' Rather, they are alive, but you perceive [it] not." ${ }^{\prime 1}$

According to Hilmi Şenalp, the architect of the monument, "[t] he dome represents a life of eternity for martyrs. It is composed of geometric arms which are a tribute to the unity and togetherness of the nation against the coup. It was this unity that stopped the coup attempt." ${ }^{2}$ The ornaments used

61 Translation from Quran.com, https://quran.com/2/154. On the monument, see also Hammond, "Making Memorial Publics," 10-14.

62 Hasan Ay, "Monument at Bridge Entrance Tribute to July 15 Coup Victims," Daily Sabah, June 18, 2017, https://www.dailysabah.com/istanbul/2017/06/19/monument-at-bridge-entrance-tribute-tojuly-15-coup-victims, accessed December 2, 2020. On Şenalp and his ties to the AKP, see Batuman, New Islamist Architecture, 30-1. 
Figure 1. The Central Monument in Ankara.

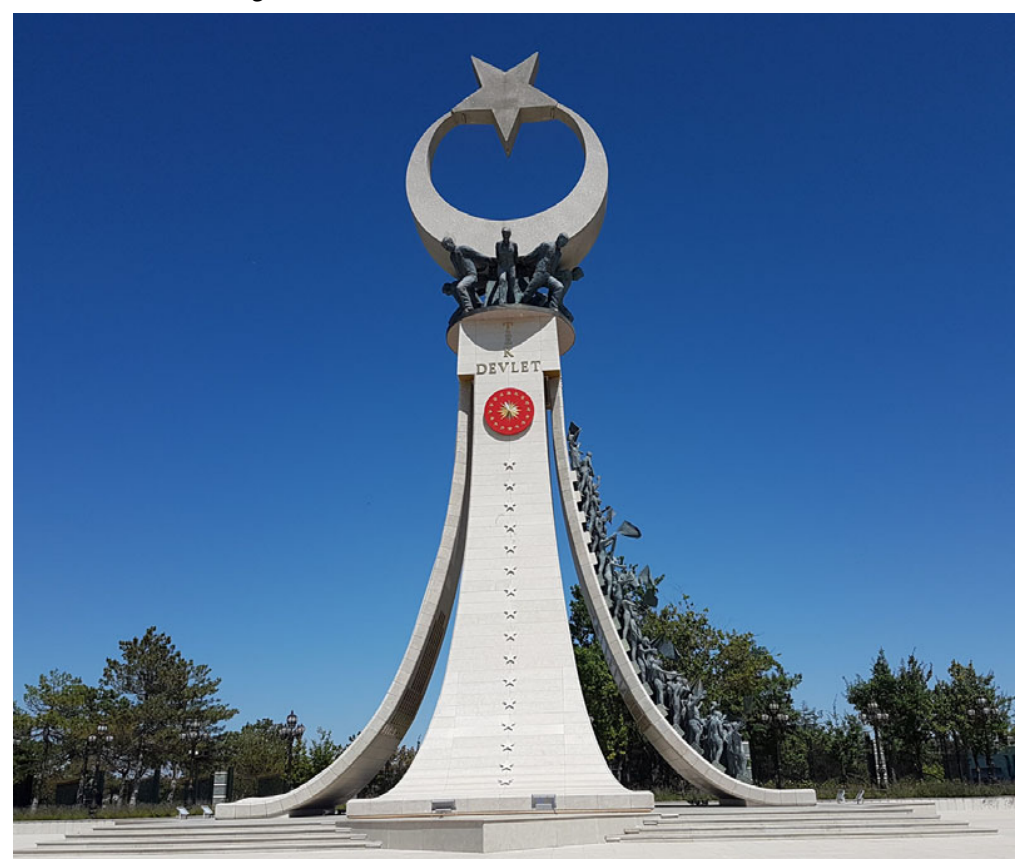

Source: Photo taken by the author, 2019.

in this monument are very different from other state-sponsored monuments and especially from Atatürk's mausoleum, Anıtkabir. While Anıtkabir contains many Turkish and Hittite archaeological elements to promote Turkish national identity and its ties to the geographical borders of the Turkish republic, ${ }^{63}$ the Istanbul monument contains many Islamic elements, thus symbolizing a shift from the Kemalist secular tradition to the more religious one of the AKP.

In contrast, the Ankara monument (see Figure 1) serves the AKP populist agenda by focusing on creating an affinity between the party and the nation while also including less explicit religious symbolism. The monument is approximately thirty-two meters tall and is based on four facets, each one of which is supposed to symbolize a different aspect of the Turkish state: "One Nation, One Flag, One Homeland, One State" ("Tek Millet, Tek Bayrak, Tek Vatan, Tek Devlet"). ${ }^{64}$ Not by coincidence, this is also the

63 On this see Wilson, Beyond Anitkabir.

64 "Cumhurbaşkanlığı Külliyesi önüne Büyükşehir'in yaptığı 15 Temmuz Şehitler Anıtı'nın inşası gece gündüz sürüyor," Büyükşehir Ankara 640, July 4-11, 2017, 12-15. "Büyükşehir'in yaptığı '15 Temmuz Şehitler Anıtı', 16 Temmuz'da sabah namazının ardından gün ağarırken Cumhurbaşkanı Erdoğan ve Başkan Gökçek tarafından açılacak", Büyükşehir Ankara 641, July 11-18, 2017, 16-17. 
AKP slogan, whose four pillars are identical with the Rabia sign of the Muslim Brotherhood. It is also considered the AKP's strategy for constructing its hegemony in Turkey, an authoritarian nationalist project that conceives the nation as a conservative Sunni Muslim millet. ${ }^{65}$ The first facet, "one nation," includes bronze figures of the people who demonstrated against the coup. In order to reflect this message of unity the figures themselves include a very diverse crowd, including men, women, and children, old and young, some of the women wearing headscarves and some of the men wearing beards. Many of the figures are also holding the Turkish flag. According to Öztürkmen, the legitimacy of "Republic Day" came from the participation of people of all classes. The fact that it was acknowledged by minorities and foreign representatives was even more important since it was in fact a "holiday for proclaiming the legitimacy of the new regime." ${ }^{\prime 66}$ The same logic can be applied to the "Democracy and National Unity Day," a holiday which is supposed to reflect the country's unity facing the coup attempt and which also symbolizes the "New Turkey."

The other facets are somewhat less interesting and include more generic national symbols such as a carving of the Turkish flag ("one flag") and a map of Turkey and the names of its provinces ("one homeland"), while "one country" includes the symbol of the presidency of Turkey and the sixteen stars representing past Turkish states. On top of the four facets there are seven figures, representing the seven regions of Turkey, bearing the Star and Crescent, the symbols of the Turkish flag. Beneath the monument a black marble slab was placed with the names of the martyrs, and the facets' inner sides are covered with small memorial plaques with the martyrs' names and pictures.

Monuments are not the only locations designated for the commemoration of July 15. As stated above, fallen soldiers are usually assigned specific spaces to distinguish them from the general population, in the form of military cemeteries. According to a report published in Hürriyet on April 21, 2017, the Turkish state had acted similarly and constructed a cemetery for the July 15 martyrs in Edirnekap1 in Istanbul. ${ }^{67}$

65 Cenk Saraçoğlu and Özhan Demirkol, "Nationalism and Foreign Policy Discourse in Turkey under the AKP Rule: Geography, History and National Identity," British Journal of Middle Eastern Studies 42.3 (2015), 301-19; Şener Aktürk, "One Nation under Allah? Islamic Multiculturalism, Muslim Nationalism and Turkey's Reforms for Kurds, Alevis, and Non-Muslims," Turkish Studies 19.4 (2018), 523-51.

66 Öztürkmen, "Celebrating National Holidays in Turkey," 58.

67 Cansu Şimşek, "15 Temmuz Şehitliği," Hürriyet, April 20, 2017, http://www.hurriyet.com.tr/gundem/ 15-temmuz-sehitligi-40433372, accessed December 2, 2020. On the cemetery see Erdem Üngür, "Edirnekapı Martyrs' Cemetery: Towards a Therapeutic Forgetting," DIYÂR 1.2 (2020), 310-31. 
Figure 2. Commemorative lira: "For the commemoration of 15 July Martyrs and Veterans."

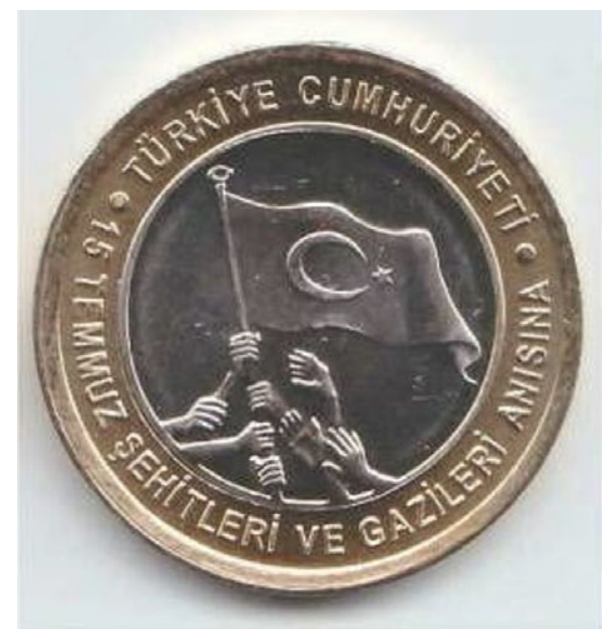

Source: Author's collection.

\section{Conclusion}

According to Esra Özyürek, since the 1990s the political Islamic movement in Turkey has defined itself as the true representative of the people, with the secular regime as the oppressor. Even after it came to power the AKP continued to define itself as a rebellious movement against the forces of the state, the army, and Western powers. ${ }^{68}$

In many instances the AKP chose to challenge the previous traditions of the secular regime and its limitations on Islam in the public sphere such as the ban on the headscarf, university registration of Imam Hatip graduates, and so on. The failed coup gave the AKP government a legitimate reason and opportunity to change one of the last bastions of "old" Turkey, its national holidays, and to shape this new holiday in accordance with the AKP agenda, including many religious expressions in the public sphere as well as some Ottoman traditions. The "Democracy and National Unity Day" is also the only event that I know of that dares to touch the memory of Atatürk, founder of the Republic. In 2017, in preparation for the first July 15 anniversary, the state minted 1 lira commemorative coins in which it replaced the portrait of Atatürk with a picture of citizens holding the Turkish flag (see Figure 2). In addition, the museum dedicated to the coup is being built on parts of "Atatürk Forest

68 Özyürek, "Commemorating the Failed Coup in Turkey." 
Farm" in Ankara. ${ }^{69}$ Interestingly, one of the ways the Ministry of Education suggested that schools commemorate the July 15 coup is by planting a forest in remembrance of the martyrs. ${ }^{70}$ Alongside the (temporary) replacement of Atatürk's portrait and the destruction of parts of Atatürk Forest Farm, the decision not to give Istanbul's new airport the same name as Atatürk Airport, which it replaced, also removed Atatürk's name from a central location in Turkey with high symbolic capital. ${ }^{71}$

Nevertheless, "Democracy and National Unity Day" is not aimed at erasing the memory of Atatürk or replacing him. We should view this, as suggested by Podeh, as an evolution of the national narrative which now includes a larger representation of the more traditional public. While it is too soon to decide whether the new holiday has achieved its purpose or not, one should remember that national celebrations are not always successful. The example of "Freedom and Constitution Day" (Hürriyet ve Anayasa Bayrami) is a case in point. The holiday, first celebrated after the 1960 coup, never attained the legitimacy of other national holidays, and was eventually abrogated in 1980.72 One should also remember that repetitive ceremonies over the years might lead the public to lose interest in these celebrations and to regard them with indifference. In addition, if the AKP's attempt to create affinity between the party and the holiday succeeds too much, it might backfire and lead to social division and alienation from the holiday by parts of the public that object to the party.

This invented holiday, its Islamic commemoration practices, and the role given to the AKP in it will remain central in Turkish public celebrations as long as the AKP stays in power, since it allows the party to gain legitimacy and frame itself as the true representative of the nation and the more traditional and conservative public. However, given the centrality of the holiday under the party, it is very likely that if the regime changes, "Democracy and National Unity Day" will be reinterpreted by the successor regime to convey its own messages, or even be abrogated completely.

69 T24, "Atatürk Orman Çiftliği'ne 15 Temmuz Müzesi: Yüzlerce ağaç kesildi, kamyonlar için yeşil alana yol açıldı," September 5, 2018, https://t24.com.tr/haber/ataturk-orman-ciftligine-15-temmuz-muzesiyuzlerce-agac-kesildi-kamyonlar-icin-yesil-alana-yol-acildi,693035, accessed December 2, 2020. On the symbolic importance of Atatürk Forest Farm in Ankara's urban history, see Batuman, New Islamist Architecture and Urbanism, 173, 176.

70 Milli Eğitim Bakanlığı, "Okullar '15 Temmuz Demokrasi Zaferi ve Şehitleri Anma' etkinliğiyle açılacak," September 9, 2016 https://www.meb.gov.tr/okullar-15-temmuz-demokrasi-zaferi-ve-sehitleri-anmaetkinligiyle-acilacak/haber/11877/tr, accessed 25 September 2019.

71 A possible explanation for that is that Atatürk Airport was not completely closed down and remained open for cargo flights.

72 Öztürkmen, "Celebrating National Holidays in Turkey", 49. 


\section{Bibliography}

Acikalin, Mehmet and Hamide Kilic. "The Role of Turkish National Holidays in Promoting Character and Citizenship Education.” Journal of Social Science Education 16 no.3 (2017): 78-9.

Adanali, Ahmet Hadi. "The Presidency of Religious Affairs and the Principle of Secularism in Turkey." The Muslim World 98 (2008): 228-41.

Aktürk, Şener. "One Nation under Allah? Islamic Multiculturalism, Muslim Nationalism and Turkey's Reforms for Kurds, Alevis, and Non-Muslims." Turkish Studies 19 no.4 (2018): 523-51.

Alayan, Samira and Elie Podeh. "Introduction: Views of Others in School Textbooks-A Theoretical Analysis." In Elie Podeh and Samira Alayan (eds.), Multiple Alterities: Views of Others in Textbooks of the Middle East. Cham: Palgrave Macmillan, 2018: 1-17.

Alderman, Derek H. "Street Names and the Scaling of Memory: The Politics of Commemorating Martin Luther King, Jr. within the African American Community." Area 35 no.2 (2003): 163-73.

Altınordu, Ateş Ali. "A Midsummer Night's Coup: Performance and Power in Turkey's July 15 Coup Attempt." Qualitative Sociology 40 no.2 (2017): 139-64.

Ay, Hasan. "Monument at Bridge Entrance Tribute to July 15 Coup Victims." Daily Sabah, June 18, 2017, https://www.dailysabah.com/istanbul/2017/06/19/monument-at-bridge-entrance-tribute-to-july-15coup-victims, accessed December 2, 2020.

Azaryahu, Maoz. "Street Names and Political Identity: The Case of East Berlin." Journal of Contemporary History 21 no.4 (1986): 581-604.

_. "From Remains to Relics: Authentic Monuments in the Israeli Landscape." History and Memory 5 no. 2 (1993): 82-103.

—. "The Power of Commemorative Street Names." Environment and Planning D Society and Space 14 no.3 (1996): 311-30.

Batuman, Bülent. "Identity, Monumentality, Security: Building a Monument in Early Republican Ankara." Journal of Architectural Education 59 no.1 (2005): 34-45.

—. New Islamist Architecture and Urbanism: Negotiating Nation and Islam through Built Environment in Turkey. Abingdon and New York: Routledge, 2018.

Bein, Amit. Ottoman Ulema, Turkish Republic: Agents of Change and Guardians of Tradition. Stanford, CA: Stanford University Press, 2011.

Ben-Amos, Avner and Ilana Bet-El. "Holocaust Day and Memorial Day in Israeli Schools: Ceremonies, Education and History." Israel Studies 4 no.1 (1999): 258-84.

Brockett, Gavin D. "When Ottomans Become Turks: Commemorating the Conquest of Constantinople and Its Contribution to World History." The American Historical Review 119 no.2 (2014): 399-433.

Büyükşehir Ankara. “Güven Anıtı'nın '15 Temmuz' yarası unutturulmayacak.” Büyükşehir Ankara 607, November 8-15, 2016: 20.

—. "Cumhurbaşkanlığı Külliyesi önüne Büyükşehir'in yaptığı 15 Temmuz Şehitler Anıtı'nın inşası gece gündüz sürüyor." Büyükşehir Ankara 640, July 4-11, 2017: 12-15.

—. "Büyükşehir'in yaptığı '15 Temmuz Şehitler Anıtı', 16 Temmuz'da sabah namazının ardından gün ağarırken Cumhurbaşkanı Erdoğan ve Başkan Gökçek tarafından açılacak." Büyükşehir Ankara 641, July 11-18, 2017: 16-17.

Çepni, Ozan. "Çocuklara 15 Temmuz! Milli Eğitim Bakanlığı, 5-6 yaşındaki çocuklara darbe girişimini soracak." Cumhuriyet, April 5, 2018, http://www.cumhuriyet.com.tr/haber/egitim/953813/Cocuklara_15_ Temmuz_Milli_Egitim_Bakanligi_5-6_yasindaki_cocuklara_darbe_girisimini_soracak.html, accessed December 2, 2020.

Çiçekoğlu, Feride and Ömer Turan, eds. The Dubious Case of a Failed Coup: Militarism, Masculinities, and 15 July in Turkey. Singapore: Palgrave Macmillan, 2019.

Çınar, Alev. "National History as a Contested Site: The Conquest of Istanbul and Islamist Negotiations of the Nation." Comparative Studies in Society and History 43 no.2 (2001): 364-91.

Dados, Nour. "Revisiting Martyrs' Square ... Again: Absence and Presence in Cultural Memory." In Ladina Bezzola Lambert and Andrea Ochsner (eds.), Moment to Monument: The Making and Unmaking of Cultural Significance. Bielefeld, Germany: Transcript, 2009: 169-81. 
Danforth, Nicholas. "Multi-purpose Empire: Ottoman History in Republican Turkey." Middle Eastern Studies 50 no.4 (2014): 655-78.

Diyanet. "Diyanet'ten 15 Temmuz'a özel hazırlık." July 5, 2018, https://www.diyanet.gov.tr/tr-tr/Kurumsal/ Detay/11737/diyanetten-15-temmuza-ozel-hazirlik, accessed September 28, 2019.

Diyanet Çocuk Dergisi 444, Temmuz 2017.

-., 456, Temmuz 2018.

-., 468, Temmuz 2019.

Doğan, Samet. "Beyazıt Kütüphanesi'nde AA'nın 15 Temmuz sergisi ilgi görüyor." Anadolu Ajansı, October 14, 2016, https://www.aa.com.tr/tr/kurumsal-haberler/beyazit-kutuphanesinde-aanin-15-temmuzsergisi-ilgi-goruyor/664956, accessed December 2, 2020.

Elgenius, Gabriella. Symbols of Nations and Nationalism: Celebrating Nationhood. Houndmills: Palgrave Macmillan, 2011.

Erdentuğ, Aygen and Berrak Burçak. "Political Tuning in Ankara, a Capital, as Reflected in Its Urban Symbols and Images." International Journal of Urban and Regional Research, 22 no.4 (1998): 589-601.

Felek Özgen and Sinem Erdoğan İşkorkutan, eds. Journal of the Ottoman and Turkish Studies Association, a special issue on "Ceremonies, Festivals, and Rituals in the Ottoman World." 6 no.1 (2019), 9-170.

Ghulyan, Husik, "The Spatialization of Islamist, Populist, and Neo-Ottoman Discourses in the Turkish Capital under AKP Rule." New Perspectives on Turkey 61 (2019), 125-53.

Ginio, Eyal. The Ottoman Culture of Defeat: The Balkan Wars and Their Aftermath. New York: Oxford University Press, 2016.

Haberler.com. "PTT A.Ş.'den 15 Temmuz Şehitlerimiz Anısına Pul Tasarım Yarışması." February 15, 2017, accessed December 2, 2020.

Hammond, Timur. "The Politics of Perspective: Subjects, Exhibits, and Spectacle in Taksim Square, Istanbul." Urban Geography 40 no.7 (2019): 1039-54.

_ . "Making Memorial Publics: Media, Monuments, and the Politics of Commemoration following Turkey's July 2016 Coup Attempt." Geographical Review (2020), https://www.tandfonline.com/doi/ full/10.1080/00167428.2019.1702429.

Hobsbawm, Eric J. and Terence Ranger, eds. The Invention of Tradition. Cambridge: Cambridge University Press, 1983.

Karateke, Hakan T. Padişahım Çok Yaşa! Osmanlı Devletinin son yüz yılında Merasimler. İstanbul: Kitap Yayınevi, 2004.

Küçük, Bülent and Buket Türkmen. "Remaking the Public through the Square: Invention of the New National Cosmology in Turkey." British Journal of Middle Eastern Studies, https://doi.org/10.1080/ 13530194.2018.1491295.

Milli Eğitim Bakanlığı, "Okullar '15 Temmuz Demokrasi Zaferi ve Şehitleri Anma' etkinliğiyle açılacak." September 9, 2016 https://www.meb.gov.tr/okullar-15-temmuz-demokrasi-zaferi-ve-sehitleri-anmaetkinligiyle-acilacak/haber/11877/tr, accessed 25 September 2019.

__. "15 Temmuz demokrasi zaferi ve şehitleri anma etkinlikleri programı." September 19-23, 2016. https://ogm.meb.gov.tr/meb_iys_dosyalar/2016_09/08101839_15_temmuz_demokrasi_zaferi_ ve_sehitleri_anma_etkinlikleri_programi_.pdf, accessed September 26, 2019.

__, "15 Temmuz Demokrasi Ve Millî Birlik Günü Anma Etkinlikleri.” April 5, 2019, http://hbogm.meb.gov. tr/www/15-temmuz-demokrasi-ve-mill-birlik-gunu-anma-etkinlikleri/icerik/912, accessed October 3, 2019.

"15 Temmuz Demokrasi ve Milli Birlik Günü." July 15, 2019. http://www.meb.gov.tr/15temmuz/ 2019/?fbclid=IwAR0sTZNW6uvVEOEa8CTqBtsoS8BPG6VbphWZQxwCfg1XPd0hGSBw6CkJum0, accessed September 24, 2019.

__. "15 Temmuz demokrasi zaferi ve şehitleri anma programı." September 18, 2019. http://img.eba.gov. tr/897/98a/3df/b4a/8f9/3a4/a0f/818/944/99f/1f4/615/154/a34/001/89798a3dfb4a8f93a4a0f81894 499f1f4615154a34001.PDF, accessed September 24, 2019.

Öktem, Kerem. "The Nation's Imprint: Demographic Engineering and the Change of Toponymes in Republican Turkey." European Journal of Turkish Studies, 7-Demographic Engineering-Part I (2008), https://journals.openedition.org/ejts/2243. 
Özpek, Burak Bilgehan and Nebahat Tanriverdi Yaşar. "Populism and Foreign Policy in Turkey under the AKP Rule." Turkish Studies 19 no.2 (2018): 198-216.

Öztürkmen, Arzu. "Celebrating National Holidays in Turkey: History and Memory." New Perspectives on Turkey 25 (2001): 47-75.

Özyürek, Esra. "Commemorating the Failed Coup in Turkey." August 18, 2016, https://www.jadaliyya.com/ Details/33489.

Parmaksı, Pınar Melis Yelsalı. "The Transformation of Citizenship before and after the 15 July Coup Attempt: The Case of Civil Martyrdom." In Nikos Christofis (ed.), Erdoğan's "New" Turkey: Attempted Coup d'état and the Acceleration of Political Crisis. London: Routledge, 2019: 113-24.

Petrone, Karen. Life Has Become More Joyous, Comrades: Celebrations in the Time of Stalin. Bloomington: Indiana University Press, 2000.

Podeh, Elie. The Politics of National Celebrations in the Arab Middle East. Cambridge and New York: Cambridge University Press, 2011.

President Erdoğan in the Beştepe People's Congress and Culture Center in Ankara, July 29, 2016. Available on the official website of the Turkish Presidency, https://www.tccb.gov.tr/MainPages/ PlayVideo?GalleryltemID=62516, accessed September 25, 2019.

Reid, Donald M. "The Symbolism of Postage Stamps: A Source for the Historian." Journal of Contemporary History 19 no.2 (1984): 223-34.

Rolf, Malte. Soviet Mass Festivals, 1917-1991. Pittsburgh, PA: University of Pittsburgh Press, 2013.

Saleem, Raja M. Ali, State, Nationalism, and Islamization: Historical Analysis of Turkey and Pakistan. Cham: Palgrave Macmillan, 2017.

Saraçoğlu, Cenk and Özhan Demirkol. "Nationalism and Foreign Policy Discourse in Turkey under the AKP Rule: Geography, History and National Identity." British Journal of Middle Eastern Studies 42 no.3 (2015): 301-19.

Schwartz, Barry. "Commemorative Objects." In Neil J. Smelser and Paul B. Baltes (eds.), International Encyclopedia of the Social and Behavioral Sciences. Amsterdam: Elsevier, 2001: 2267-72.

Shaw, Wendy M.K. Possessors and Possessed: Museums, Archaeology, and the Visualization of History in the Late Ottoman Empire. Berkeley: University of California Press, 2003.

Şimşek, Cansu. "15 Temmuz Şehitliği." Hürriyet, April 20, 2017, http://www.hurriyet.com.tr/gundem/15temmuz-sehitligi-40433372, accessed December 2, 2020.

Solomonovich, Nadav. "The Turkish Republic's Jihad? Religious Symbols, Terminology and Ceremonies in Turkey during the Korean War 1950-1953." Middle Eastern Studies 54 no.4 (2018): 592-610.

Star, "Devletin zirve mekanlarına '15 Temmuz Destanı' yazılıyor." July 14, 2017, https://www.star. com.tr/yerel-haberler/devletin-zirve-mekanlarina-15-temmuz-destani-yaziliyor-103517/, accessed December 2, 2020.

Şünbüloğlu, Nurseli Yeşim, "Contending Sacrifices: Discontent of Military Veterans of the Kurdish Conflict for Civilian Veterans of 15 July." In Çiçekoğlu and Turan, The Dubious Case of a Failed Coup, 41-70.

T24, "Atatürk Orman Çiftliği'ne 15 Temmuz Müzesi: Yüzlerce ağaç kesildi, kamyonlar için yeşil alana yol açıldı." September 5, 2018, https://t24.com.tr/haber/ataturk-orman-ciftligine-15-temmuz-muzesiyuzlerce-agac-kesildi-kamyonlar-icin-yesil-alana-yol-acildi,693035, accessed December 2, 2020.

Taş, Hakkı. "The 15 July Abortive Coup and Post-truth Politics in Turkey." Southeast European and Black Sea Studies, 18 no.1 (2018): 1-19.

Terzioğlu, Derin. "The Imperial Circumcision Festival of 1582: An Interpretation." Muqarnas 12 (1995): 84-100.

The Presidency of Religious Affairs. "The Glorious Resistance that Salas [Prayers] Bore Witness: 15 Temmuz." July 14, 2017, http://www2.diyanet.gov.tr/DinHizmetleriGenelMudurlugu/HutbelerListesilngilizce/The\% 20Glorious\%20Resistance\%20That\%20Salas\%20Bore\%20Witness;\%2015\%20Temmuz.pdf, accessed September 28, 2019.

TRT, "15 Temmuz Kahramanları." http://www.trt.net.tr/15temmuzkahramanlari/, accessed October 5, 2019.

Üngür, Erdem. "Edirnekapı Martyrs' Cemetery: Towards a Therapeutic Forgetting." DIYÂR 1 no. 2 (2020): 310-31. 
Uzer, Umut. "Glorification of the Past as a Political Tool: Ottoman History in Contemporary Turkish Politics." The Journal of the Middle East and Africa 9 no.4 (2018): 339-57.

Vinitzky-Seroussi, Vered and Chana Teeger. "Unpacking the Unspoken: Silence in Collective Memory and Forgetting." Social Forces 88 no.3 (2010): 1103-22.

Wilson, Christopher S. Beyond Anitkabir: The Funerary Architecture of Atatürk-The Construction and Maintenance of National Memory. Farnham: Ashgate, 2013.

Yavuz, Hakan and Rasim Koç. "The Turkish Coup Attempt: The Gülen Movement vs. the State." Middle East Policy, 23 no.4 (Winter 2016): 136-48.

Yavuz, Hakan M. "A Framework for Understanding the Intra-Islamist Conflict between the AK Party and the Gülen Movement." Politics, Religion \& Ideology 19 no.1 (2018): 11-32.

Yılmaz, Hale. Becoming Turkish: Nationalist Reforms and Cultural Negotiations in Early Republican Turkey, 1923-1945. Syracuse, NY: Syracuse University Press, 2013.

Yilmaz, Zafer. "The AKP and the Spirit of the 'New' Turkey: Imagined Victim, Reactionary Mood, and Resentful Sovereign." Turkish Studies 18 no.3 (2017): 482-513.

Zencirci, Gizem. "Secularism, Islam and the National Public Sphere: Politics of Commemorative Practices in Turkey." In Alev Cinar, Srirupa Roy, and Maha Yahya (eds.), Visualizing Secularism and Religion: Egypt, Lebanon, Turkey, India. Ann Arbor: University of Michigan Press, 2012: 93-109.

Zerubavel, Yael. "Battle, Sacrifice, and Martyrdom: Continuity and Change in the Conception of Patriotic Sacrifice in Israeli Culture." In Avner Ben-Amos and Daniel Bar-Tal (eds.), Patriotism. Tel Aviv: Hakibbutz Hameuchad \& Dyonon, 2004: 61-99 (in Hebrew). 